\title{
An Economic Case for Regulating Against the Use of Non-Deposit Carrying Glass Containers of Beverage in South Africa
}

\section{S Hosking}

Department of Economics, University of Port Elizabeth

\section{ABSTRACT}

As a result of minimal private cost many people dispose of non-deposit bearing glass containers in ways which cause glass pollution: hazardous broken bottles and litter. This pollution imposes costs on users of the affected environment and on municipalities, which have most of the responsibility to clean up, although in South Africa the two main glass packaging producers also play a role by operating a recycling system. A case study was carried out in the Port Elizabeth area in which exploration is made of the glass that does not get recycled and an intuitive analysis is made of the costs of different options for managing recyclable glass waste. It is concluded that the case deserves further investigation for introducing legislation in South Africa making bottle deposits mandatory.

JEL K 200

\section{INTRODUCTION}

From an environmental perspective one of the most promising ways to deal with glass packaging pollution is to recycle it. If reprocessed and used again, alcoholic and soft drink container bottles do not deface the landscape or add to the mound of refuse generated by the modern industrial 'throw away' society ultimately requiring burial in municipal tips. Fortunately, under some circumstances it is profitable to recycle glass bottles, and as a result, a recycling glass bottle industry has evolved.

Despite the development of this industry, the problem of glass bottle waste still remains an acute environmental problem in South Africa. For this reason the question arises of whether the government should not step in and help remedy a problem the market is failing to, by introducing more regulation in the beverage bottling industry. 
It is not an option to be adopted on weak grounds, because this type of regulation can undermine economic freedom (Barry, 1994: 6). Specifically, if the government legislated a mandatory deposit-refund system covering all soft and alcoholic drinks, the freedom to enter into contracts for beverages contained in non-refundable glass bottles would be lost. This paper will explore the economic case for this option, using Port Elizabeth as a case study

\section{THE NATURE OF THE PROBLEM}

This type of regulation is not new in the world. It is usually called container deposit legislation elsewhere. In the United States discussion of container deposit schemes can be traced back to the 1930s (W.D. Scott and Company Pty. Ltd., August, 1983: 10). The legislation encompasses containers of all types of beverage. (The type of regulation being considered in this report merely relates to glass.)

The following states of the United States of America had introduced bottle bill (container deposit) legislation by 1989: California, Connecticut, Delaware, lowa, Maine, Massachusetts, Michigan, New York, Oregon and Vermont (Tietenberg, 1992: 206). There is similar legislation in Canada (Turner, Pearce and Bateman, 1993: 259-260). In Australia, South Australia introduced container deposit legislation in 1977 (Business Regulation Review Unit, June, 1989:11). There has also been strong support for various aspects of container deposit legislation on the continent of Europe. The following European countries have product charge or deposit-refund legislation covering beverage containers: Austria, Sweden, Finland, Germany, Norway, Switzerland and Denmark (Turner, Pearce and Bateman, 1993: 259-260).

In South Africa legal protection of the environment can only be justified if it is in human interests; the legal principle being, cum igitur hominum causa ius constitutio sit (law is an institution for the sake of men) (Rabie, 1973:1). Currently, legal protection against careless disposal of glass bottles is justified in terms of this legal principle on the grounds that, like other littering, it is an eye-sore and or health risk for other human users of the environment. The protection takes the form of litter deterring provisions in the Environmental Conservation Act (No. 73) of 1989. In terms of Section 19 of the Act a fine of R1 000 and/or 3 months imprisonment may be imposed on a person for littering a public attraction. In sections $20-24$, regulations and directions of waste management are dealt with. They provide for the imposition of fines of up to R100 000 and/or 10 years imprisonment on people who dispose of waste illegally. Is this enough, or should the government be doing more? 
Of the representatives spoken to in the beverage industry in South Africa, few were prepared to commit themselves on the desirability of container deposit legislation in South Africa. Most representatives spoken to did not foresee it as likely in the near future and redirected inquiries on the issue to Owen Bruyns, Executive Director, Packaging Council of South Africa (PACSA), Johannesburg. Telephonic and face to face discussions were held with $\mathrm{Mr}$. Bruyns on the topic during second half of 1996. He is of the view that the case for regulating against non-retumable bottles is weak because:

- regulation is unnecessary - the bottle manufacturers are already addressing the problem, by administering non-profit making glass recycling systems (e.g., bottle banks),

- the impact of the proposed regulation has been researched in other countries (USA and Australia) and shown to be an inefficient solution to the problem of glass litter,

- it will not solve the relevant problem but merely change the nature of it the relevant consumers will simply switch from disposable glass containers to disposable tinplated steel and aluminum cans and to disposable plastic PET bottles,

- it will reduce consumer surplus by reducing choice and pushing up the prices of the relevant beverages (because they will be more costly to produce), and

- it will reduce jobs and income (and thereby tax receipts) in the glass bottling and beverage industries and/or divert capital to the distribution and cleaning sectors.

The first of these arguments is the one primarily addressed in this paper. The second is addressed in sections 2 and 3 , but the following issues are not addressed:

- possible consumer substitutions of glass for plastic, aluminum and tinplated containers,

- possible changes to beverage prices, and

- possible changes to employment and income totals in different industries, e.g., due to reductions in some types of bottle production and increases in other, and to increases in recycling activities. 
FINDINGS OF SELECTED OTHER STUDIES INTO THE ECONOMICS OF LEGISLATING AGAINST NON-RETURNABLE BOTTLES

The studies to which PACSA refer are those on container deposit legislation by W.D. Scott and Company Pty. Ltd. (August, 1983) and the Business Regulation Review Unit (June, 1989) - both relate to the case of Australia. They are discussed under (a) and (b) below.

(a) W.D. Scott and Company Pty. Ltd. (August, 1983) analyzed the probable economic impact of introducing container deposit legislation throughout Australia and concluded that:

- it would increase the cost of soft drinks and beer in cans and plastic containers, and for this reason also their retail prices, as well as the retail price of drinks in multifill containers (to help cover these increased costs),

- skilled or semi-skilled manufacturing jobs would be replaced by unskilled bottle sorting and handling jobs, with the result that employee earnings would decline,

- government revenue would decline because sales would decline, profits would decline, employee income would decline and production plants would be written off, as unprofitable plants were closed down, e.g., tinplated steel can producers,

- overall energy consumption would decrease, but more scarce primary energy sources would be used due to increased transport requirements (less hydroelectricity, coal and natural gas, but more oil),

- the raw materials used in the beverage container industry of Australia are abundant in the country,

- the experience of South Australia with mandatory deposit legislation was that the reduction in costs of litter management were insignificant - only a $3 \%$ reduction in total litter, and

- alternatives to mandatory deposits are more cost effective in reducing litter and conserving resources than mandatory deposits, e.g., improving return rates on existing multifill packages, improving recycling rates and funding comprehensive litter reduction campaigns.

(b) The Business Regulation Review Unit (June 1989) considered the same topic as W.D. Scott and Company Pty. Ltd. (August, 1983), but a few years later. It noted that between 1973 and 1978 counts of litter fell by $80 \%$ in the state of South Australia and that container deposit legislation was introduced there in 1977. In South Australia mandatory deposits apply to all beer, wine cooler, soft drink and milk containers. The Business Regulation Review Unit were not of the view that this reduction 
was purely and simply due to the introduction of the relevant legislation, because some years prior to 1977 there had been vigorous anti-litter media campaigns in the state and the introduction of on-the-spot fines for littering. Moreover, impressive reductions in litter also occurred in states where there was no container deposit legislation, e.g., $63 \%$ in New South Wales between 1979 and 1985 and $50 \%$ in Victoria between 1983 and 1988.

Some of the negative features of container deposit legislation were:

- it imposes a particularly high deposit on cans, which cannot be reused, thereby raising the overall price of the product and reducing demand,

- it increases production and retailing costs (bottle washing plants, storage of bottles at retailers, slower bottle filling compared to cans and increased distribution costs),

- it increases consumer costs by making them return bottles, and

- it increases the cost of market entry (e.g., beer from Western Australia) thereby facilitating local monopolies.

The conclusion of the Business Regulation Review Unit was that the cost savings, brought about by container deposit legislation as a result of reduced garbage disposed, were far outweighed by the increased costs this legislation imposed on consumers and producers. The Unit suggested that more efficient ways of reducing costs would be privatizing waste disposal operations, media campaigns, increased littering fines and appealing to beverage and container producers to avoid ring tops (on cans) and other devices that can add to the problem of litter.

One of the well known cost benefit studies carried out on bottle deposit legislation in the United States is that of Porter's (1978).

(c) Porter (1978) conducted a cost benefit study of a proposal to legislate, in the state of Michigan in the USA, for the introduction of mandatory deposits on beer and soft drinks containers. The proposal was to make all beverage containers sold in the state of Michigan subject to a returnable deposit of 10 cents. At the time only $27 \%$ of the containers were retumable. His conclusion was that it depended upon the relative valuations of the average citizen's time sacrifice cost and willingness to pay for a reduction in container litter. For instance, he calculated that a desirability of mandatory deposits equated to an aggregate willingness to pay about $\$ 200$ million per annum (by the 9,1 million citizens), or $\$ 27.26$ per annum per citizen (assuming the average citizen's time return cost 
were equal to the 10 cents deposit proposed). Porter suggests that this sum may be higher than what the citizens would be prepared to pay for a reduction in container litter. However, it is noted that his justification for a return cost estimate equal to 10 cents per retumable bottle is based on a rather extreme assumption; that the return cost of the non-returnable bottle is trivial and can be ignored. What Porter's analysis strongly suggests is that no general answer may be given to the question of whether mandatory deposits are desirable.

(d) Based on the findings of a cross-section of cost benefit studies done on deposit-refund systems in Europe and the United States, Turner, Pearce and Bateman (1993: 264-265) conclude that they do not generate significant net social gains. The problem, as they see it, is that they do not reduce the overall volume of municipal waste enough to offset the additional administrative costs.

(e) Although little support has been found amongst industrial groups in the United States for government legislated deposit-refund systems, the general public have been very supportive of them (Turner, Pearce and Bateman , 1993:255). There is evidence that the public respond positively to changes in the pricing of waste disposal. The examples of Highbridge and Seattle show how changing the incentives to dispose of litter have worked in the United States (Tietenberg, 1992).

- In January, 1988, the town of Highbridge in New Jersey, USA, replaced its flat $\mathbf{2 8 0}$ dollar annual fee for the collection of refuse with a fee that varied with the amount of trash (New York Times, 24 November, 1988, B1,B7). Each household was given 52 stickers for 140 dollars. Additional stickers could be bought at 1.25 dollars each. As a result peoples attitudes towards wastes changed rapidly: the amount of refuse required to be collected went down $25 \%$ as residents began to compost food and yard wastes and recycling programmes flourished in glass, newspapers and cans. In 1989 the base sticker rate was increased to 200 dollars and additional stickers to 1.65 dollars each. This increase gave rise to concerns that the new pricing strategy for refuse removal was going to place a greater burden on the poor. However, that concern was apparently misplaced. Under the old system every household paid the same fee for refuse collection, regardless of how much refuse was put out, and as poorer households were producing less refuse, they were in effect subsidising the wealthier ones. 
- Seattle, Washington instituted a similar system, but with higher prices. They too experienced a dramatic decline in refuse disposal and increase in recycling.

The lesson learned is that when the incentive not to waste is made direct, people change their behavior and waste less. The refund system is similar in its effect $A$ deposit must be paid by the consumer, on the purchase of the recyclable item, which reflects the cost of recycling or disposing of it. Glass bottles and aluminum cans are good examples of such items, but there are also many others to which the system has been successfully applied, including cars and car parts (Bohm, 1981, pp.120-124). On returning the item to a designated dealer a refund is given. This refund creates the incentive for someone, not necessarily the purchaser, to collect the item and transport it to the designated dealer. If the purchaser considers the incentive insufficient to return it, an opportunity for others, probably poorer people, is created to make money out of the system by returning it.

\section{THE MARKET DETERMINISD EFFICIENT LEVEL OF GLASS RECYCLING}

Investigations of the literature on recycling confirm that in an efficient market, devoid of any imperfections, there is no need for intervention because the interaction of supply and demand bring about an efficient level of recycling (Tietenberg, 1992). In this kind of market the rising costs of virgin materials and of waste disposal increase the attractiveness of recycling from both the demand and supply sides of the market. Products relying exclusively on virgin raw materials would be subject to higher prices than those drawing on recycled materials. Consequently, consumers would switch from products relying exclusively on virgin raw materials to ones drawing on recycled materials; a switch known as the composition of demand effect (Tietenberg, 1992).

The theory that there is an efficient level of recycling glass waste in South Africa does not relate to all glass but only to that which is potentially profitable to recycle; mainly to glass used as packaging (bottles and jars).

There are many private economic incentives to recycle glass. Glass containers of beverage are almost $100 \%$ recyclable, which means they can be recycled with minimal loss of material, or emission of toxic waste, over and over again. Moreover, recycled glass melts at lower temperatures than the raw materials used for glass production. For each $10 \%$ increase in recycled glass containers 
added to the mix, the melting energy required is reduced by about $2,5 \%$. As a result both energy usage and wear and tear on capital (the fuirnaces) are reduced; two of the main costs incurred in producing glass (Glass Recycling Association, November, 1996). In the furnaces, molten glass is heated up to a temperature of between 1260 and $1480^{\circ} \mathrm{C}$.

Notwithstanding these energy and capital saving incentives, there are limits to the amount of glass that it is profitable to recycle. The main limiting factors are the collection, processing and transport costs. At some point the energy and capital saving of using recyclable glass is outweighed by the greater acquisition cost of cullet (crushed used glass packaging) over that of the virgin raw materials used in the glass mix (pers. comm., Owen Bruyns, 1996). It is a point which is reached fairly quickly in South Africa, because the virgin raw materials used to make glass are plentiful: silica sand $(58,1 \%$ of the mix required), soda ash $(18,2 \%)$, limestone $(15,6 \%)$, feldspar $(4,4 \%)$ and dolomite $(3,7 \%)$. There is also a quality deterioration problem (increased bubbles in the finished products) if more than $\mathbf{4 0 \%}$ of the input material used to make glass is made up of cullet (Vogler, 1981:173). This limiting factor is also relevant in Australia (Business Regulation Review Unit, June, 1989: 35).

Of potentially recyclable glass about $65 \%$ recycles in South Africa: about $43 \%$ in the form of returnable bottles and about $22 \%$ through bottle bank and buy back systems set up by the Glass Recycling Association (Glass Recycling Association, November, 1996). Glass recycling with retumable bottles is generally found to be more cost effective than with non-returnable ones (Vogler, 1981: 178).

It is deduced that the market choice in South Africa is to recycle $65 \%$ of packaging glass. If efficient markets are assumed it is deduced that of the potentially recyclable glass $35 \%$ is inefficient to recycle (the profit incentive is insufficient).

\section{RECYCLING BY SELECTED BOTTLING COMPANIES IN SOUTH AFRICA}

\section{Soft drinks}

According to PACSA, as a proportion of the total volume packed in returnable and non-returnable containers, the volume of soft drinks packed in returnable (voluntary deposit) containers in South Africa increased from 65\% to $67,4 \%$ between 1990 and 1993. Of the returnable bottles in 1993: 54\% were 1 litre glass bottles, $7,3 \%$ were 1,5 litre plastic bottles and $6,1 \%$ smaller glass bottles. 
Of the non-returnable containers: $65 \%$ were metal cans (as against $40 \%$ in 1990 ) and $27 \%$ plastic bottles. By comparison with the United States a much higher proportion of soft drinks are packaged in returnable containers in South Africa. In the United States this proportion is only about 8\% (PACSA, 1996). The main bottling company of non-alcoholic beverage (Coca Cola) in South Africa, the South African Bottling Company (SABCO), has its head office in Port Elizabeth. In November 1996 it reported that $67 \%$ of the packaging done by it was in glass containers, and $57,11 \%$ of the glass packaging was in returnable containers (Emie van Vuuren, Manager SABCO, November, 1996). About $6 \%$ of the returnable bottles are damaged in the return process. Whereas non-returnable bottles are merely rinsed, returnable ones first have to be sorted (which is very labour intensive), the caps removed, and then washed. Dave Davies, also of SABCO (production manager), is of the view that consumer preferences are shifting from soft drinks packed in returnable containers to ones packed in non-returnable containers, but no evidence was offered to support this view (November 1996). The converse appears to be true in the beer market.

\section{Beer}

For the period, June 1986 to January 1994, South African Breweries reported to PACSA that as a proportion of total sales of all malt beer in South Africa, the market share of:

- returnable re-usable voluntary deposit containers increased from about $72 \%$ to $79 \%$ (and the $750 \mathrm{ml}$ specifically, from $64 \%$ to $75 \%$ ),

- non-returnable metal cans increased from $6 \%$ to $10 \%$, and

- non-returnable dumpies decreased from $9 \%$ to $7 \%$.

It appears that since 1993 the swing away from non-returnable to returnable containers has continued in the beer market. In November, 1996, South African Breweries Port Elizabeth office (Owen Kingwall, Production Manager, November, 1996) reported that of its total sales, market shares by types of container were roughly as follows:

- $80 \%$ in $750 \mathrm{ml}$ 'quarts' (returnable),

- $10 \%$ in $375 \mathrm{ml}$ 'pints' (returnable),

- $5 \%$ in $340 \mathrm{ml}$ 'dumpies' (non-returnable), and

- $5 \%$ in cans (non-returnable).

A returnable beer bottle can be re-used up to 30 times per bottle (Owen Kingwall, South African Breweries, Production Manager, November, 1996). 
RECYCLING IN PRACTICE IN SOUTH AFRICA

In South Africa the Glass Recycling Association administers glass recovery systems. This association was formed in 1986 by the main two glass packaging producers in South Africa, Consol Glass and Metal Box Glass. The rationale this association provides for its activities is 'to promote the concepts of a clean environment and a healthy community' ('A Message From the Glass Recycling Association', November 1996). It employs two methods of glass recovery: a bottle bank system and the buy back system.

The bottle bank system works by consumers putting their unwanted glass jars and bottles into one of about 1490 glass bottle banks set up in 115 cities and towns in South Africa, and agents of the company collecting this glass from these banks.

Traffico is the agent appointed to administer the bottle banks in Port Elizabeth. There are currently about 54 of them in the city. It collects about $3 / 4$ ton of glass per week from these 54 bottle banks (Willem Jordaan, Operations Manager, Traffico, November 1996).

The buy back system is a repurchase arrangement with 120 appointed agents in designated areas in South Africa. The arrangement is for the purchase by Consol Glass of crushed used glass packaging, known as cullet. To qualify as cullet and be repurchased by these companies:

- only bottle and jar glass should be used

- glass should be separated by colour (into amber, green, flint or mixed), and

- no contaminants should be mixed in amongst the jar and bottle glass - any other type of material, including other types of glass (such as window, light bulb, drinking and crystal), and

- the glass should be crushed (culled) and transported to either of the Johannesburg or Cape Town Consol Glass plants.

In Port Elizabeth, Traffico sees to it that these requirements are met. The bottle banks only make up part of its supply. SABCO supplied it with 29 tons of glass in 1996; bottles damaged in the process of production (Emie van Vuuren, SABCO, January, 1997). 'Totting rights' to collect glass waste at the municipal tip site in Port Elizabeth also yield it a supply (Ken Kendel, PE Municipality, November, 1996), as does South African Breweries in the form of their damaged bottles (Owen Kingwall, Production Manager, South African Breweries, November, 1996). 
WHERE THE MARKET (AND CONSUMER MORALITY) FAILS

The motivation provided by the Glass Recycling Association for its recycling activities is moral (rather than profit). It suggests implicit acceptance of a weak version of the producer pays principle by the two main glass packaging producers in South Africa, i.e., acceptance that part of the disposal cost relating to the non-returnable bottles is their responsibility. We may deduce that they feel that the other part lies with the consumer, in the form of a moral obligation to take the non-returnable bottle, from which they consume the contents, to one of the many bottle banks they provide.

This position is a reasonable one in an era when the public is continually urged to be environmentally conscious, and environmental education and awareness campaigns are regularly conducted.

However, in many circumstances, taking a bottle to the bottle bank is neither the most efficient action to take, nor the one people will necessarily be inclined to take. For a self-interested person, the most efficient action with respect to non-deposit bearing glass containers is to discard them as soon as possible after the consumption of their contents, because this imposes the lowest private cost on them. Minimizing the return cost is undoubtedly the main reason why people would want to purchase this type of bottle instead of the returnable one. On privately owned land, this means in a general refuse bin, and on common or government land, this means in the park, on the beach, alongside the walkway, or on the street. For people who are more sensitive to the social benefits of responsible behaviour with respect to litter, one would expect them to make the effort to take their non-returnable bottles to the bottle banks. However, even for these people, there are circumstances where they may not do this. For instance, if they perceive large numbers of others about them not making the effort, they may deduce that their actions are of so little consequence that they cease to bother themselves (i.e., the public good 'assurance' problem).

For these reasons (despite public education and awareness campaigns) $35 \%$ of the glass packaging industry's total output of about 125000 tons per annum ends up either being buried in landfills, together with other refuse or left on the ground, frequently in broken pieces (Glass Recycling Association, November, 1996). In landfills the external cost is passed on to the municipal rate payers (estimated at R15 million per annum for South Africa) and to refuse workers who are injured in the process of transporting it pieces (Glass Recycling Association, November, 1996). When left on the ground the external cost of packaging glass waste is more difficult to estimate, but it may be even greater than for the landfill case. Left broken on the ground it is time consuming to 
pick up, it detracts from the visual appeal of the environment and is physically dangerous to those barefoot. The problem is particularly evident at places where picking up glass must be done by hand, litter spoils the look and feel of the place, and where it is natural for people to want to walk barefoot, for instance, the beach. Recreational values are reduced. Significantly, on many beaches glass litter is simply left by the administering authorities, presumably because the cost of cleaning up is prohibitively high (see Port Elizabeth case study below).

To sum up: an important cost is left out of the calculus that underlies the market outcomes on what is recycled in South Africa, namely, the cost that is incurred in disposing of the $35 \%$ of glass produced per annum, not recycled. Currently part of this external cost problem is borne by local governments, in the form of refuse collection, cleaning operations and municipal tip management, and part by the citizens living and using the environments where the glass packaging is disposed.

The question this paper addresses is whether this external cost can be reduced by making a deposit-refund system mandatory for glass beverage packaging, without increasing other costs by more than what is saved.

\section{ASPECTS OF GLASS WASTE DISPOSAL IN PORT ELIZABETH}

\section{Glass waste - a municipal perspective}

The city of Port Elizabeth collects about 1000 tons of solid waste per day from households and firms (Ken Kendell, Chief Cleansing Officer, November 1996). The costs of refuse collection amount to about R23,5 million. In addition about R15,3 million is spent on cleaning up streams and beaches. The cleansing division of the PE municipality employs about 730 people and spends more than $\mathrm{Rl}$ million per week in total on cleaning.

A domestic refuse analysis conducted in 5 suburbs in Port Elizabeth (Summerstrand, Hollard Park, Newton Park, Sydenham and Framesbury) for the city of Port Elizabeth shows that glass accounts for about $7 \%$ of the weight of the refuse and $2 \%$ of the volume (Table 1). 
Table 1: Cumulative constituents analysis of 5 samples of domestic refuse in Port Elizabeth.

\begin{tabular}{|l|c|c|c|}
\hline Constituents & $\begin{array}{l}\text { Sample Weight } \\
\text { (kgs) }\end{array}$ & $\begin{array}{l}\text { Weight \% of } \\
\text { Sample Total }\end{array}$ & $\begin{array}{l}\text { Volume \% of } \\
\text { Sample Total }\end{array}$ \\
\hline Paper & 249,85 & 18,1 & 38,04 \\
\hline Glass & 99,3 & 7,9 & 2,36 \\
\hline Metal & 43 & 3,11 & 3,97 \\
\hline Plastic & 50,5 & 3,66 & 13,96 \\
\hline Veg. \& Putrescible & 497,55 & 36.04 & 11,62 \\
\hline Garden Refuse & 373 & 27,02 & 25,85 \\
\hline Rags & 13,5 & 0,98 & 1,41 \\
\hline Unclassified & 29,6 & 2,14 & 0,68 \\
\hline Wood \& Combustible & 24,25 & 1,76 & 2,11 \\
\hline Totals & 1380,55 & 100 & 100 \\
\hline
\end{tabular}

Source: City of Port Elizabeth, Chief Cleansing Officer, November 1996.

As a result of broken glass bottles being placed in black refuse bags, about 2 injuries per week are sustained by refuse collectors firms (Ken Kendell, Chief Cleansing Officer, November, 1996). Mostly these injuries are superficial cuts, but there also have been deep leg cuts and kidney damage reported. The presence of glass is also dangerous for those who seek to collect specific items from the refuse at the municipal tip site; which is the reason why the PE municipality is currently considering installing an expensive a conveyer belt system at the tip site.

\section{Glass waste on the beaches}

The highest concentration of Port Elizabeth's glass pollution is found on its beaches and recreational areas, especially on its northem beaches, where the highest numbers of beach-visitors are found (Ken Kendell, Chief Cleansing Officer, November, 1996). On New Year's Day, 1994/5, about 132000 people visited PEs northern beaches of Joorst Park, St. Georges, and Wells Estate, and about 92000 PEs southern beaches of Kings, Humewood, Hobie and Pollock (95/96 Summer Season Lifesaving Report, City of Port Elizabeth). Of the incidents reported by the lifeguards at Humewood and Hobie beaches during the 1995/96 Summer Season Lifesaving Report :

- 8 were for cuts,

- 39 for 'helpouts',

- 2 for sprains or fractures, and

- 3 for stings. 
There were 10 injuries reported as being the result of broken glass by lifeguards on the northern beaches of Port Elizabeth (Joorst park, Wells Estate and St. Georges Strand); two of which were considered serious. The senior lifeguard for the area (Armand) was of the view that excessive use of alcohol was a contributing factor to the problem of glass litter on the beach. He deduced that inebriated people did not to think or care about the health risk imposed on other beach users resulting from the disposal of glass on the beach.

One of the most common types of glass litter found on the beaches of the Port Elizabeth (PE) area is the non-returnable beer dumpie; mainly containers sold by South African Breweries. The buyers of these containers constitute a niche market for South African Breweries - $10 \%$ of the total market (Owen Kingwall, South African Breweries, November 1996). These consumers are happy to pay a bit more for their beer in order to avoid the time and transport cost of returning the bottles after consuming their - presumably the more affluent section of the market Beer bought in single-fill bottles is a bit more expensive than that bought in returnable ones, after the deposit for the bottle has been claimed - usually between 3 and $8 \%$.

The problem of glass litter is also evident on other beaches near PE, but outside PE municipal control. During 1996 Jean Spearpoint and David Brown monitored solid waste litter on a 100 square metre section of the beach adjacent to the Van Stadens Mouth Resort. The cleaning up of the beach is the responsibility of the Department of Culture and Recreation, Eastern Cape, and the Eastern Cape Conservation department. Access to the Van Staden Mouth Resort and beach is controlled and takes the form of a R15 entry fee per car levied by the Department of Culture and Recreation, Eastern Cape, at the entrance to the resort. They recorded details of any litter they found in random walks during the 6 months from May to October 1996. The results of this study are presented in tables 2 to 4 below.

Table 2: Composition of pollution according to the material of items of litter picked up in random walks May to October, 1996, on a 100 metre stretch of beach at Van Stadens Gorge.

\begin{tabular}{|l|c|c|}
\hline Material littered & Number of items & $\%$ of total \\
\hline Glass & 507 & 86 \\
\hline Metal cans & 76 & 13 \\
\hline Plastic & 6 & 1 \\
\hline
\end{tabular}


Table 3: Number of units of glass and weight of broken glass picked up in random walks May to October 1996, on a 100 metre stretch of beach at Van Stadens Gorge.

\begin{tabular}{|l|c|c|}
\hline Month in 1996 & Number of Units & $\begin{array}{c}\text { Weight of broken } \\
\text { glass in Kgs }\end{array}$ \\
\hline May & 53 & 1,82 \\
\hline June & 67 & 5,45 \\
\hline July & 94 & 2,84 \\
\hline August & 131 & 1.14 \\
\hline September & 114 & 3,64 \\
\hline October & 48 & 2,39 \\
\hline Total & 507 & 17,28 \\
\hline
\end{tabular}

Table 4: Proportion of items of glass pollution made up of deposit bearing containers and non-deposit bearing.

\begin{tabular}{|l|c|}
\hline Type of glass bottle & $\%$ \\
\hline Deposit bearing & 7 \\
\hline Non-deposit bearing & 93 \\
\hline
\end{tabular}

The particularly interesting aspect of this research is that it indicates what litter one could expect to come across on the beach after organized cleaning has taken place. Glass is the litter one is most likely to come across and $93 \%$ is in the form of non-deposit bearing glass containers.

Mike Bentall, Chief Environmental officer for the East London municipality, reported that similar problems are encountered in East London's public places (August 1996).

The public's view on the disposal of glass bottles in Port Elizabeth

During November 1996, H. Gous carried out a limited public survey of people's views in Port Elizabeth on the disposal of glass bottles. The survey method employed was personal interviews with people randomly selected from the more affluent suburbs of Port Elizabeth. The selection of people from the more affluent suburbs was motivated by the small scale of survey proposed and the observation that in the beer market, non-returnable bottles were targeted at the wealthier consumers - poorer ones (the majority) preferring the returnable containers because the beer is cheaper out of them. Had poorer people been included in the survey we would have expected a far smaller proportion of the 
sample to indicate that they purchased non-returnable bottles. A total of 100 people, aged from 18 to 57 years, were interviewed.

Of those interviewed (100):

- 96 knew which beverage containers were deposit bearing,

- 45 buy returnable glass bottles only, if the option exists,

- 85 purchase between 1-5 bottles of beverage per week , 10 purchase 6-10 bottles and 5 were unsure,

- 60 disposed of their non-returnable bottles in the bottle banks provided by the Glass Recycling Association, and

- 35 regarded the use of bottle banks as too inconvenient.

M. Akkerman undertook a similar survey in the Northern Suburbs of Cape Town during November, 1996, but asked some additional questions - ones focusing on why people do not use the recycle systems currently available. He interviewed 16 people. Of these people:

- all thought that the recycling of glass was a good idea in principle,

- 13 knew which beverage containers were deposit bearing and which not (although some expressed confusion with respect to bottles containing beverages other than soft drinks and beer),

- 10 regarded returning non-returnable bottles for recycling as inconvenient, and

- 13 thought that they should be compensated monetarily for time and costs incurred in returning bottles for recycling.

\section{Glass as hazardous waste}

Much of the glass collected in Port Elizabeth is not recyclable (see Oliver, 1975, on the making and using of glass other than for packaging). This glass is disposed of by being treated with chemicals to immobilize heavy metals, compacted and covered at a hazardous landfill site. Waste Tech gives assistance in the process on request (Susan Alcock, Waste Tech, November, 1996) and also itself disposes of some hazardous glass waste. It removes glass waste from Shatterpruffe, ELMOSA and Associated Glassworks. 


\section{TOWARDS A CASE FOR REGULATION}

\section{The object of Regulation}

A model is provided in Figure 1 (below) where the aim of regulation is described.

\section{Figure 1: A Single Market Model of the Case for Regulation}

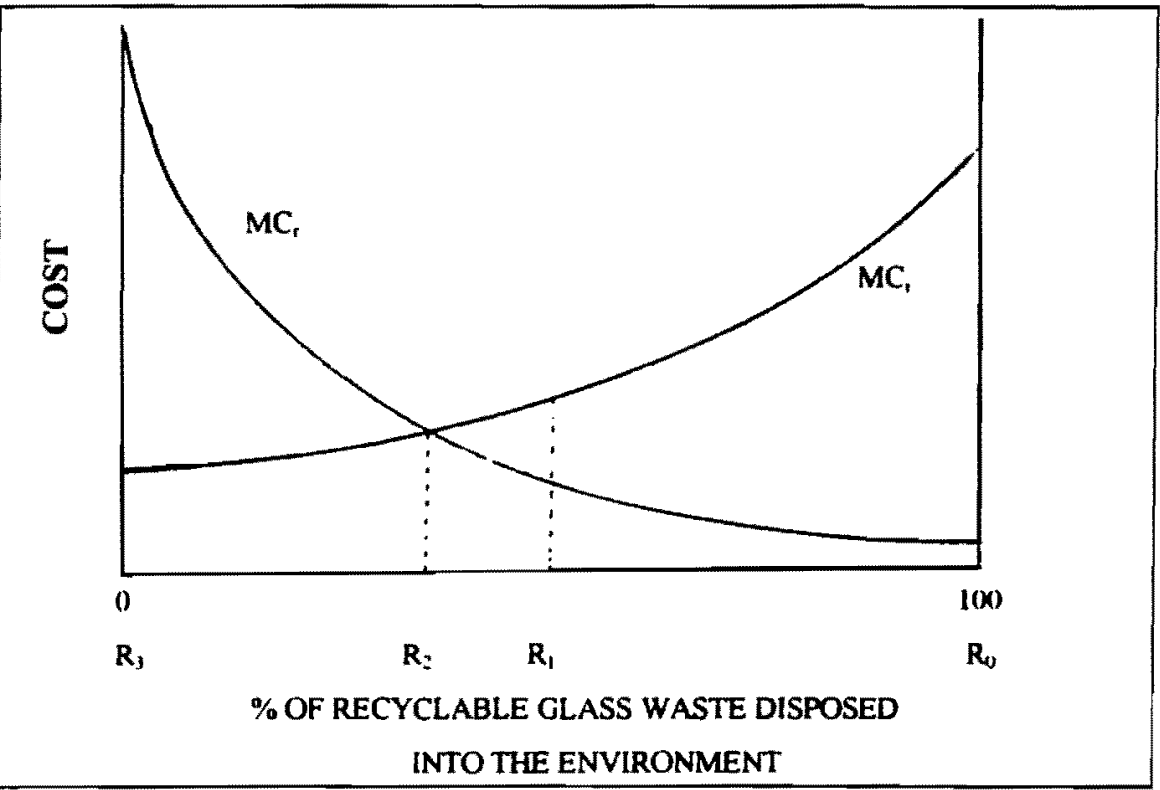

In Figure 1 two functions are shown: $M C_{r}$ and $M C_{i}$. The negatively sloped one $\left(\mathrm{MC}_{\mathrm{r}}\right)$ shows the marginal social cost of reducing the amount of glass packaging disposed into the environment. The positively sloped one $\left(\mathrm{MC}_{i}\right)$ shows the marginal social cost of increasing glass packaging disposed into the environment.

The object of regulating glass packaging disposal is to bring about an optimal level of waste disposal, which, assuming convexity in the damage and abatement functions (Perman, Ma and Mcgilvray, 1996: 200-212), is where:

$\mathrm{MC}_{\mathrm{r}}=\mathrm{MC}_{\mathrm{i}}$

In order to achieve this $R_{0} R_{2}$ glass packaging waste must be diverted from the environment. 
The relevance of all this for government is that, if market generated recycling only induces a diversion of $R_{0} R_{1}$ waste from the environment, the government needs, some way or other, to effect an additional diversion of $\mathbf{R}_{\mathbf{1}} \mathbf{R}_{\mathbf{2}}$ waste, in order to facilitate an optimal level of glass waste disposal.

\section{Instruments of Regulation}

There are various ways governments may set about this objective. The most popular four economic instruments are :

- increasing the imposition of waste disposal charges (a curbside charge on consumers - based on volume or weight) and fines for littering,

- levying a product charge (packaging tax) on the sales of producers of non-refundable beverage containers, to cover the costs expected to be incurred in final disposal,

- $\quad$ subsidizing recycling production, and/or

- legislating a deposit-refund system with respect to all containers (Turner, Pearce and Bateman, 1993: 259-260).

Each option has problems associated with it (Turner, Pearce and Bateman, 1993: 260-266). For instance, increasing curbside waste disposal charges can lead to people either disposing of their waste in other ways which negatively impact on the environment, or adding theirs to someone else's bundle, and it can be administratively costly. A packaging tax does not directly discourage irresponsible waste disposal, only indirectly, by raising prices and so reducing demand. Its main attribute is that it raises revenue to cover the environmental costs of the waste disposal. Subsidizing recycling systems requires tax payers to bear part of the consumers disposal cost and so in effect is an income transfer. The main problem with respect to the deposit refund system is the cost benefit studies have not shown it to generate significant net social benefits.

\section{The cost benefit approach}

The desirability of the above listed littering abatement measures depends upon the marginal cost of damage from final disposal being greater than the marginal cost associated with implementing that particular measure. The issue reduces to one of whether the marginal cost of damage to the final environment is greater than the marginal cost of implementing a deposit-refund system for glass bottle containers of beverage.

One approach to shedding light on the issue is to conduct a cost benefit analysis of the proposed legislation at the margin, i.e., using incremental costs. In this 
context the cost benefit model advocated by Porter (1978) is popular (Common, 1996:347). The approach is one of using the net present value (NPV) decision rule - the legislation is only deemed to be desirable if the NPV is positive. For the case this paper is investigating the NPV would need to be defined as follows:

$N P V=\sum_{t=1}^{T}\left(B_{1 t}+B_{2 t}+B_{3 t}-C_{1 t}-C_{2 t}-C_{3 t}\right) /(1+r)^{i-1}$

where,

$B_{1 t}=$ the social valuation of the cost saving benefit of the municipality and other government institutions in collecting and disposing of glass waste,

$\mathrm{B}_{2 \mathrm{t}}=$ the cost saving benefit in reduced inputs required to produce the glass containers for soft and alcoholic drinks,

$B_{3 t}=$ the social valuation of the benefit of fewer glass litter related accidents and less amenity (or eye-sore) damage,

$\mathrm{C}_{\mathrm{lt}}=$ the increased cost of inputs used to put soft and alcoholic drinks into containers and of collecting and administering the expanded refillable container system,

$\mathrm{C}_{2 \mathrm{t}}=$ the increased cost of greater litter related accidents and amenity (or eyesore) damage caused by non-returnable non-glass container substitutes for glass ones purchased by consumers,

$\mathrm{C}_{3 \mathrm{t}}=$ the social valuation of the increased time cost to households in returning empty refillable bottles,

$r$ = the discount rate, and

$\mathrm{t}=$ number of years after legislation is implemented; $t=1 \ldots . . \mathrm{T}$.

There is little doubt that this approach has the potential to yield useful information, but the information requirements of it are considerable (see Porter, 1978); beyond the terms of reference of this exploratory study. The estimation of $B_{3 t}$ and $C_{3 t}$ would require contingent valuations to be carried out amongst residents and visitors to the area. Many cost benefit studies conducted overseas on the issue have not yielded significant positive net present values (Turner, Pearce and Bateman , 1993: 264-265).

\section{An intuitive approach}

This paper does not use a cost benefit analysis approach in order to weigh up the case for bottle deposit legislation, but an intuitive reasoning approach. For this purpose an expanded version of the model in Figure 1 is adopted - see 
Figure 2 (overleaf). In it four marginal social cost functions are incorporated: $M C_{i}, M C_{r}, M C_{r d}$ and $M C_{m}$.

The $M C_{i}$ curve in Figure 2 is as it was for Figure 1, but the $M C_{r}$ curve is defined differently. In the model described in Figure 2, the recycling of non-returnable bottles is distinguished from that of returnable bottles; the reasons being that the costs of recycling and the target consumer markets differ. South African Breweries described the market they provide non-returnable containers for as a niche one (see section 6 above). Presumably niche markets are catered for by beverage suppliers because the economies of scale benefit of producing beverage in standard packaging is outweighed by the increased sales revenue benefit gained by dividing up the beverage market through different packaging and advertising. A more complex $\mathrm{MC}_{\mathrm{r}}$ curve is defined when this division is taken into account:

$M C_{r}=M C_{r d}$ from $R_{0}$ to $R_{1}$ (for the returnable share of the glass container market), and

$=\mathrm{MC}_{\mathrm{m}}$, from $\mathrm{R}_{1}$ to $\mathrm{R}_{4}$ (for the non-returnable share of the glass container market), where,

$\mathrm{MC}_{\pi \mathrm{d}}=$ the marginal social cost of recycling deposit bearing refillable bottles, and

$\mathrm{MC}_{\mathrm{m}}=$ the marginal social cost of recycling non-deposit bearing single fill bottles (e.g., through the bottle bank system).

The return cost of different types of bottle is assumed to be equal from the consumer's point of view (implying $C_{3 t}=0$, or that the cost of returning a bottle to the bottle bank is equal to returning one to a beverage bottle retailer), but not from the beverage supplier's. As most of the profitable glass packaging recycling is done in refillable bottles, and the recycling which is being done in single fill bottles is mainly sustained on moral rather than commercial grounds, it is deduced that:

$\mathrm{MC}_{\mathrm{rd}}<\mathrm{MC}_{\mathrm{m}} \cdot$

The division between the recycling market for returnable and non-returnable bottles is shown in Figure 2 by the vertical dotted line above $R_{2}$. 
Figure 2: A split market model of the case for regulation.

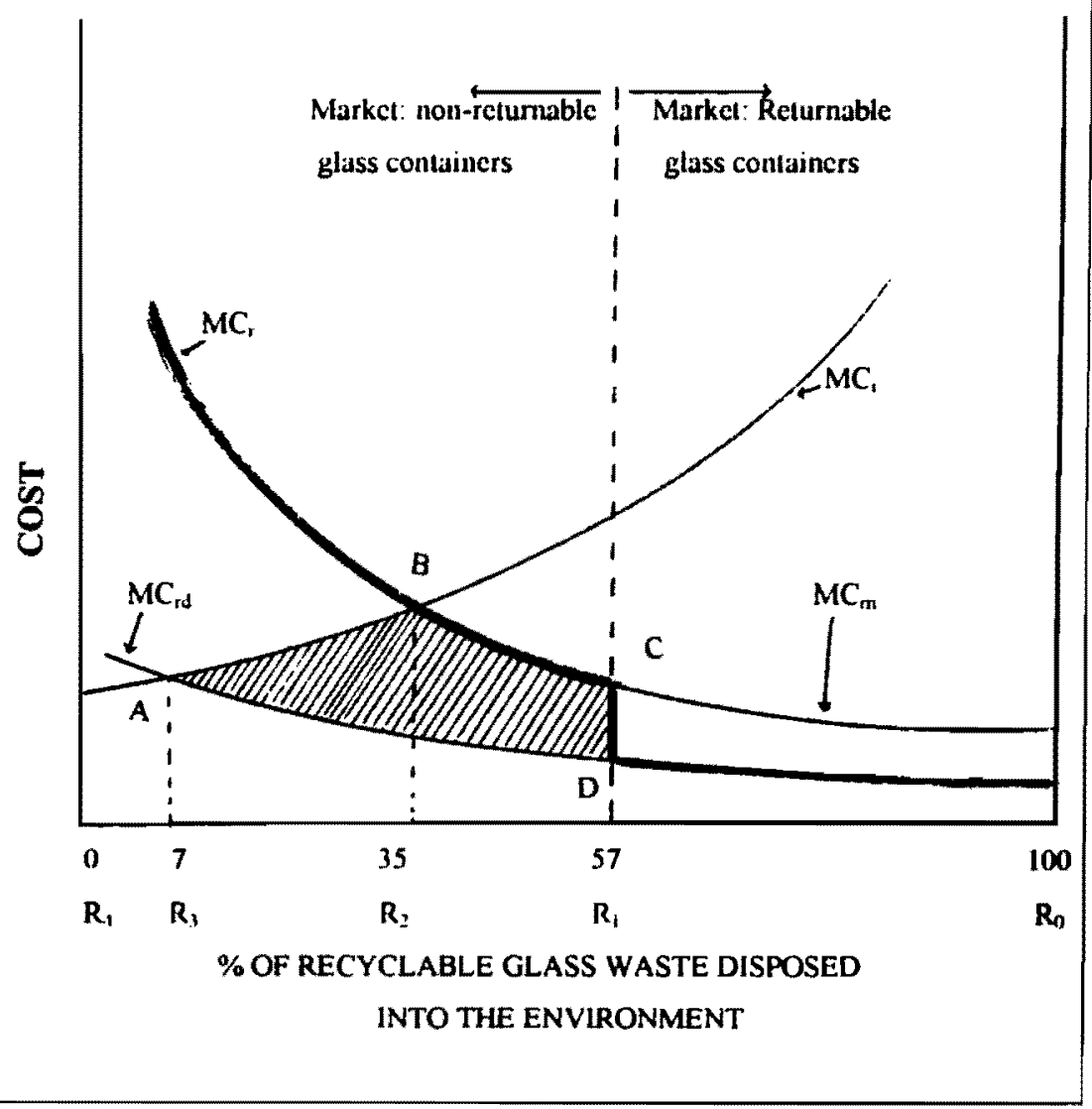

The case for a mandatory deposit-refund system rests on the benefit of removing the market division between non-returnable containers and returnable ones. With the removal of this market division, the efficient level of recycling increases from $R_{0} R_{2}$ to $R_{0} R_{3}$. As a result, total costs equal to the shaded area $A B C D$ are saved; the vertical difference between the $M C_{r d}$ and the lesser of the $M C_{i}$ and $M_{m}$ curves. It is a cost which is quite likely to increase steadily in the future, as citizen opposition mounts to the siting of existing and new tips, so pushing up tipping costs (Goldstein, 1995: 358).

In principle it is conceivable that this gain through regulation could be offset by the loss in profits and income gained by the beverage seller and others (like advertisers) in servicing niche markets. However, as the beverages can be 
purchased cheaper from refillable bottles, it appears that much of the profit and income gained through niche market creation, may be a transfer of consumer surplus to advertisers and the beverage producing companies, rather than reflect a net social benefit.

Trends in South African beer and soft drink markets are consistent with this interpretation. South African Breweries, being overwhelmingly dominant in the beer industry in South Africa during the 1980s and early 1990s, displayed a diminishing interest in promoting product differences based on differences in glass packaging options - more and more of their beer was sold in refillable bottles. (It is conceivable that this trend may be reversed if new competitors enter the industry and challenge their market dominance.) In the soft drink market, by comparison, where competition is more evident, more attention is focused on differences in packaging.

To sum up: the case for regulating that a deposit-refund system operate in South Africa for all glass bottle containers of beverage is based on the external cost saving exceeding the profit gain lost in niche markets. It is a plausible case because the costs of recycling refillable bottles is less than that of non-refillable bottles and the profit and income loss in the non-refillable bottle market is mainly a transfer of consumer surplus to the beverage producers and the advertisers they commission.

\section{CONCLUSIONS ON REGULATING AGAINST NON-DEPOSIT BEARING GLASS CONTAINERS OF BEVERAGE}

In principle there are many solutions to the problem of glass pollution: educating consumers to be more responsible, encouraging producers to bear the burden of the external cost, and placing the burden of this cost on consumers, by restricting their choice only to glass containers which are deposit bearing. The latter approach provides consumers with an income incentive to recycle the glass containers, and so hamesses self-interest as its primary driving force. The disposal cost of the container is thereby internalized.

It is concluded that it is an efficient option because:

- Private costs would be brought into equivalence with social costs and most bottle glass waste (over $90 \%$ ) would never reach final environments. In principle a litter tax on glass bottle producers can bring about the same end result (after cleaning up operations) but it would not prevent glass from reaching final environments. 
The potential external cost saving is uncontroversial.

Besides being an efficient option, mandatory glass bottle deposit legislation for alcoholic and soft drinks also may advantage the following:

- local businesses over foreign ones, because imported beverages (like beer, wine and whisky) would probably need to be packaged locally instead of abroad in order to fit in with the requirements of the local deposit-refund system, and

- labour over capital, because a labour intensive production system is favoured over a capital intensive one in an economy with a huge surplus of labour.

In reaching this conclusion several potential negative spin-offs of the proposed regulation were not investigated. The most important of these spin-offs are increased product prices and substitutions in production and consumption that aggravate other types of pollution problem, e.g., those of plastic, tinplated steel and aluminum waste. The prices of beverage in returnable containers could be raised as a result of reduced physical sales volumes or the need to recoup forgone profit on the non-retumable containers. However, it also bears noting in this connection that:

- physical sales volumes of refillable containers of beverage could be expected to increase, thereby making it possible to derive greater economies of scale in production, and

- plastic, tinplated steel and aluminum waste problems could (and perhaps should) be simultaneously addressed, as is commonly done in European countries where container deposit legislation has been introduced, e.g., through the levying of charges on products using these types of packaging. The latter approach would also have the merit of being less distorting with respect to the market for packaging material.

For the above reasons it is recommended that further investigation be conducted into the merits of introducing mandatory bottle deposit legislation into South Africa.

\section{ENDNOTE}

Funding from the Human Sciences Research Council (HSRC) for this investigation is gratefully acknowledged, as is the assistance with field work by Mr. M. Akkerman, Mr. H. Gous, Mrs. J.G. Hosking, Mrs. J. Spearpoint and Mr. D. Brown, and the comments of the anonymous referees of the HSRC. This paper is drawn from a research report submitted to the HSRC on 9 February 1998. 


\section{REFERENCES}

1. BARRY, N. (1994) 'The Market, Liberty and Regulatory State'. Journal of the Institute for Economic Affairs, 14 (4), 5-12.

2. BOHM, P. (1981) Deposit-Refund System: Theory and Application to Environmental, Conservation and Consumer Policy. Baltimore: John Hopkins.

3. BUSINESS REGULATION REVIEW UNIT (June, 1989) 'Container Deposit Legislation and the Control of Litter and Waste', Information Paper No. 14. Report for the Ministry of Industry, Technology and Commerce, Australia.

4. COMMON, M. (1996) Environmental and Resource Economics: An Introduction. (Second Edition.) London: Longman

5. GOLDSTEDN, E.S. (1995) Economics and the Environment. New Jersey: Prentice Hall

6. OLIVER, D.S. (1975) The Use of Glass in Engineering. Oxford: Oxford University Press.

7. PORTER, R.C. (1978) 'A social cost benefit analysis of mandatory deposits on beverage containers', Journal of Environmental Economics and Management, 5, 351-375.

8. RABIE, A. (1976) South African Environmental Legislation. Pretoria: The Institute of Foreign and Comparative Law, UNISA.

9. SCOTT, W.D. AND COMPANY PTY. LTD. (AUGUST, 1983) 'Study of the Economic Impact of Beverage Container Deposit Legislation'. Commissioned by Brewers, Soft Drink Fillers and Container Manufacturers in Australia.

10. TIETENBERG, T.H. (1992) Environmental and Natural Resource Economics (Third Edition) New York: Harper Collins.

11. TURNER, R.K., PEARCE, D. AND BATEMAN, I. (1993) Environmental Economics: An Elementary Introduction. Baltimore: John Hopkins.

12. VOGLER, J. (1981) Work from Waste. London: Intermediate Technology Publications Limited. 